\title{
Wartime Sexual Violence: Assessing a Human Security Response to War-Affected Girls in Sierra Leone
}

\author{
MYRIAM S. DENOV* \\ McGill University, Canada
}

\begin{abstract}
Wartime sexual violence continues to be widespread and systematic in contemporary conflicts. Although the problem is gaining increasing international attention, it has remained, for the most part, peripheral within the domain of security studies. However, the human security agenda may have the capacity to raise the profile of wartime sexual violence and offer a useful framework from which to understand and respond to the unique needs of war-affected girls and women. This article explores the capacity of the human security agenda, both conceptually and practically, to address the plight of girl victims of sexual violence in the aftermath of Sierra Leone's conflict. Drawing upon the perspectives and experiences of three girls formerly associated with Sierra Leone's Revolutionary United Front, the article traces the extreme forms of sexual violence and insecurity girls were forced to endure, both during and following the conflict. It also examines a number of human security efforts implemented in the conflict's aftermath and their impact on the level of empowerment, protection and security of girls. The broader implications of these human security efforts are explored in light of the girls' lived realities in post-conflict Sierra Leone.
\end{abstract}

Keywords sexual violence $\cdot$ human security $\cdot$ girls $\cdot$ war $\cdot$ Sierra Leone affected by war both directly and indirectly (Gardam \& Charlesworth, 2000). The direct effects include victimization through acts of murder, terrorism, torture and rape, while the indirect effects include displacement, loss of home or property, family separation and disintegration, poverty, and illness (Ashford \& Huet-Vaughn, 1997). There has been mounting evidence suggesting that women and girls experience armed conflict differently than men and boys (Gardam \& Charlesworth, 2000; Mack, 2005), 
with females usually being the more insecure, disadvantaged and marginalized (SAP Canada, 2002). This is because armed conflict often exacerbates the gender inequalities that exist in different forms and to varying degrees in all societies, and that make women and girls particularly vulnerable when conflict erupts. The predominance of sexual violence ${ }^{1}$ against females during war provides a powerful example of this phenomenon. Women and girls have been ongoing targets for sexual violence during conflict because of their ethnicity, but mainly because of their gender, and their bodies are used as figurative and literal sites of combat (Twargiramariya \& Turshen, 1998).

Historically, sexual violence has been routinely directed against females ${ }^{2}$ during armed conflict (Seifert, 1996), and it was prevalent in the wars of the ancient Greeks, Romans and Hebrews, as well as in the Trojan War (Niarchos, 1995). In the 20th century, mass sexual violence has been documented during the first and second world wars, the Vietnam War and, over the last few decades, in the conflicts in El Salvador, Guatemala, Liberia, Kuwait, Rwanda, former Yugoslavia and many others. The numbers of sexually victimized females during recent conflicts have been staggering, with estimates ranging in the tens and hundreds of thousands (Ashford \& HuetVaughn, 1997; Twagiramariya \& Turshen, 1998). For example, during the eleven-year civil war in Sierra Leone (1991-2002), sexual violence was committed on a much larger scale than the highly visible amputations for which Sierra Leone became notorious. Throughout the civil war, thousands of women and girls of all ages, ethnic groups and socio-economic classes were subjected to widespread and systematic sexual violence, mostly by rebel forces. ${ }^{3}$ In 2002, Physicians for Human Rights (2002) conducted a survey of female heads of households in communities of displaced persons. The organization calculated that as many as 215,000 to 257,000 Sierra Leonean women and girls may have been subjected to sexual violence during the conflict period. ${ }^{4}$ Moreover, thousands of Sierra Leonean women and girls were abducted by rebel forces and confined among their ranks for long periods of time. Required to perform multiple roles that included domestic, espionage and combat activities, vast numbers of these women and girls were repeatedly raped and forced into sexual slavery (Denov \& Maclure, 2006).

Despite the occurrence of wartime sexual violence throughout history, the problem was long ignored by historians, journalists and academics, and dismissed by military and political leaders as a 'private crime' or the 'unfortu-

${ }^{1}$ In this article, 'sexual violence' is the overarching term used to describe 'any violence, physical or psychological, carried out through sexual means or by targeting sexuality' (United Nations, 1998).

2 Importantly, males are also victims of wartime sexual violence (see Zarkov, 2001). This article, however, is focusing solely on sexual violence against females.

${ }^{3}$ Sexual violence was also reportedly committed by the civil defence forces, the Sierra Leonean army and the West African peacekeeping force ECOMOG.

4 This calculation is not inclusive of all categories of victims: to the internally displaced women reporting conflict-related sexual violence, Physicians for Human Rights added non-conflict-related sexual violence among non-displaced women, assuming a prevalence rate of $9 \%$. 
nate behaviour' of renegade soldiers (Seifert, 1996). Over the past decade, however, wartime sexual violence has gained increasing attention, as evidenced by the burgeoning literature on the topic (see Niarchos, 1995; Skjelsbaek, 2001; Green, 2004). Nonetheless, the growing recognition of the problem has been frequently undermined by its marginal status within the overarching realm of security studies. With its focus on traditional notions of state survival, sovereignty and security, the security studies literature has tended to overlook security issues surrounding gender and violence (Hoogensen \& Rottem, 2004). However, with the increased recognition that territorial security does not necessarily ensure the security of citizens within a state, at the forefront of a new debate is the concept of human security. With its bottom-up approach and its emphasis on individual actors, while simultaneously attempting to ensure the protection and empowerment of citizens, the human security agenda may have the capacity to raise the profile of wartime sexual violence and offer a useful framework from which to understand and respond to the unique needs of war-affected girls and women.

This article explores the capacity of the human security agenda, both conceptually and practically, to address the plight of war-affected girls and victims of sexual violence in the aftermath of Sierra Leone's conflict. Given its history of profound violence, Sierra Leone has been chosen as a case study as it provides an interesting and important lens through which to explore issues of human (in)security and wartime sexual violence, and may also help to shed light on issues relating to gendered (in)security in other parallel contexts. The article begins with a brief overview of Sierra Leone's civil war and its impact on children, particularly girls. Drawing upon the voices of three war-affected girls, the article highlights the extreme forms of insecurity girls were forced to endure, both during and following the civil war. The human security agenda is then examined, particularly its capacity to respond to the security needs of girls in post-conflict societies. Finally, the article examines a number of human security efforts in Sierra Leone and their impact on the level of empowerment, protection and security of the everyday lives of the three girls. The broader implications of these efforts are explored in light of the girls' lived realities.

\section{Sierra Leone's Civil War and Its Impact on Children}

The precursors to Sierra Leone's decade-long civil war are intricate and multifaceted and can be linked to a weakened state, structural violence, the economic power of the diamond trade and growing mass disillusionment. With its legacy of colonialism and slave resettlement, Sierra Leone was integrated into the world system in a way that left its traditional social systems 
largely shattered and its economy controlled by a small group of international enterprises and a kleptocratic governing elite. With poor governance and a frail economy, there were few viable educational and economic opportunities available to young people, who make up nearly half of the country's population. In a country caught up in a spiral of institutional decay and widespread impoverishment, traditional institutions were gradually replaced by militarized structures that were sustained by extraordinary violence (Richards, 1998). Drawing upon the mounting disillusionment among the young, former Sierra Leone army corporal Foday Sankoh, backed by Liberian warlord Charles Taylor, formed the rebel Revolutionary United Front (RUF) - a 'movement' against the corrupt and inefficient Sierra Leonean government. In March 1991, the RUF invaded Sierra Leone from Liberia. Despite the RUF's political rhetoric calling for 'liberation', 'emancipation' and 'democracy', it was extreme forms of violence that appeared to pervade both the formal and informal culture of the RUF (Abdullah, 1998). In fact, the RUF's so-called democratic revolution appeared to be fought not through the political realm, but instead through the pillage of rural institutions and industrial assets, the mass looting of village property and, perhaps most disturbingly, brutal violence against the very civilians it was claiming to liberate.

Sierra Leonean children, ${ }^{5}$ both boys and girls, were easily engulfed in the conflict. While there is evidence to suggest that some children joined the ranks of the RUF willingly (Peters, 2004), the majority of children were abducted from their families and communities and press-ganged into armed conflict (McKay \& Mazurana, 2004; Maclure \& Denov, 2006). In many cases, the acquiescence to the norms of violence and terror, either as aggressors or as unwilling victims, became children's only recourse for survival.

For children, life among the RUF was both brutal and terrifying. An aura of fear and menace, repeatedly articulated through verbal, physical and sexual abuse, was an integral feature of daily interactions, and the ongoing violence ensured total compliance with their new reality. Alongside being witnesses to and victims of wanton cruelty, through intense forms of indoctrination, coercion and desensitization, many boys and girls eventually became participants in armed aggression and took on roles as active combatants and commanders of other children (Denov \& Maclure, in press-b). Without family or community support or the capacity to escape the throes of the RUF, these children were caught up in a severe culture of violence and terror.

\footnotetext{
${ }^{5}$ Reflecting Article 1 of the UN Convention on the Rights of the Child, a child is defined as 'every human being below eighteen years'.
} 


\section{Girls in the RUF: Sexual Violence and the Culture of Terror}

Given the highly militarized and patriarchal structure of the RUF, as well as the secondary status of females within its ranks, girls, who made up approximately $30 \%$ of the RUF, were among the least secure, particularly with regard to sexual violence. Although forced to endure a variety of forms of victimization and forced perpetration amid the RUF, Sierra Leonean girls have reported that it was the pervasive sexual victimization that was most debilitating (Human Rights Watch, 2003; Denov \& Maclure, 2006). Given the little attention dedicated to girls associated with armed groups, there is insufficient understanding of their wartime experiences of sexual violence or their long-term security needs, particularly post-conflict. Hoogensen \& Rottem (2004: 156) note the importance of not only responding to the security needs of those who are the least secure (such as girls), but also of ascertaining these needs from the perspectives of the individuals themselves. It is therefore essential to explore girls' experiences of wartime sexual violence and insecurity in order to develop protective security strategies, both during and following conflict, that are grounded in the views of the girls themselves. By relying on the voices and perspectives of three girls formerly associated with the RUF, the present article highlights girls' unique experiences of wartime sexual violence and insecurity.

\section{Methodological Considerations: Researching War-Affected Girls}

The three girls interviewed for this research were participants in a larger study on war-affected boys and girls in Sierra Leone. The selection of children for the study was facilitated by Sierra Leonean research partners at Defence for Children International, Sierra Leone (DCISL) who had ongoing contact with war-affected children through the course of their daily work. Researchers from DCISL purposively selected a sample of children (40 boys and 40 girls) with whom they were in regular contact in the eastern, southern and northern provinces and the western area of Sierra Leone. To be included in the study, participants were required to have been associated with an armed group in Sierra Leone (whether voluntarily or under coercion) while under the age of 18 . No stipulations were made regarding the length of time that children were attached to an armed group, or their assigned role within the group.

Between May 2003 and February 2004, the research team, consisting of both 
Sierra Leonean and Canadian researchers, conducted a series of interviews with these children, most of whom were interviewed twice. Staff members of DCISL conducted a first round of semi-structured interviews with the children in their own native languages (Krio, Mende, Temne and Limba). These interviews were audio-taped and subsequently transcribed and translated into English. These first transcripts facilitated the study of the lives and family backgrounds of the children prior to the war, the circumstances of their recruitment into the RUF and their subsequent experiences with the rebels. Several months later, with the assistance of interpreters, the author conducted a second round of one-to-one interviews with the same children. These interviews served to probe topics covered in the first round of interviewing, as well as to explore other emerging themes, and they were likewise audio-taped, translated and transcribed.

The safety and protection of all participants were, of course, crucial aspects of this project. No interview was conducted without obtaining the full and informed consent of each child, as well as that of their parent or guardian. Participants were guaranteed anonymity and assured that all information gathered would remain confidential and used for research purposes only. There were, however, important risks to consider. Participants were being asked to share potentially traumatic and painful events, which could evoke varying levels of distress. Those who were still suffering from the trauma of war and its related effects could experience heightened anxiety by speaking about it in detail. Individuals who were coming to terms with their experiences of violence could have been afraid to reopen old wounds. Additionally, participants could fear reprisal or stigmatization as a result of sharing their stories. The research posed other important ethical challenges, particularly with regard to the profound disparities of power existing between adult researchers and child participants. The research team was thus highly aware of the potential for re-victimization, making the ethical implications of the research a central aspect of the ongoing training and dialogue of the entire research team. Support structures were put into place to ensure that child participants were provided with ongoing support and assistance during and in the aftermath of interviews. This came in the form of assistance from local social workers and child protection agencies, family and community members, and members of the research team who met with children following interviews, in both the short and the long term.

Although there is often a culture of silence surrounding sexual violence, participants were generally open and forthcoming with their perspectives and experiences. This was likely facilitated by DCISL's reputation as a defender of children's rights in Sierra Leone, by its existing community relationships, and by the trusting relationships developed between many of the respondents and the research team over the course of the two-year project. The 'outsider' status of the Canadian researchers and their obvious 
lack of involvement in the conflict also appeared to facilitate open discussions with children.

At the time of the fieldwork, each of the three girls presented in this article was between 14 and 17 years old, and living in Freetown. The girls had been abducted by the RUF and remained under their control for periods ranging from several months to seven years. Although the study collected the life histories of 40 boys and 40 girls, the narratives of Kadiatu, ${ }^{6}$ Maria and Hawa are presented here because their stories effectively embody the (in)security experiences of many war-affected girls and are illustrative of broader social processes. While their narratives have been truncated due to limited space, they nonetheless provide a snapshot of the girls' lived realities during and following the conflict. ${ }^{7}$

\section{Narratives of Wartime Sexual Violence and Insecurity}

\section{Kadiatu}

Kadiatu was approximately 14 years old at the time of the interview. ${ }^{8}$ She was living on the streets of Freetown and surviving on prostitution. She was first met by the research team at a police station in Freetown, where members of DCISL provided her with free legal representation following a public altercation with a client. Grateful for the support, Kadiatu began regular visits to the offices of DCISL and later expressed an interest in participating in the study. Kadiatu reported being abducted by the RUF at a very early age (possibly age 4) and remembers nothing of her biological family. Raised within the ranks of the RUF by a commander and his wife, the RUF had been the only family she had ever known:

I grew up with the RUF and all I knew was the RUF. . . As a very young girl, I helped with domestic work. . . . Later on, I was recruited to go into combat and became very involved in fighting. I was about ten years old when I became part of the fighting forces. The RUF believed that once a girl had attained puberty and started having sex, she was physically mature enough to become a soldier. After I was raped, I was recruited into the forces.

${ }^{6}$ All names have been changed for reasons of confidentiality.

7 It is important to consider the limitations of presenting truncated versions of girls' narratives of sexual violence and insecurity. First, these condensed narratives precluded salient contextual information on the girls' lives and experiences, limiting a degree of nuance and complexity. Second, highlighting girls' experiences of sexual victimization and insecurity may reproduce stereotypes of war-affected girls as passive victims, ultimately obscuring their capacity for agency, resistance and volition. In fact, girls demonstrated unique, resourceful and often subversive means to resist RUF authority structures and command, ultimately demonstrating their capacity for agency and resistance during and following conflict. However, an in-depth discussion of girls' agency and resistance was beyond the scope of the current article. For a discussion of war-affected girls' agency and their active negotiation of security, see Denov \& Gervais (2006). For a discussion of the contexts and lives of study participants, see Denov \& Maclure (2006).

${ }^{8}$ Having been abducted as a young child, Kadiatu was unsure of her precise chronological age. 
Although Kadiatu experienced extreme forms of physical and emotional abuse during her years with the RUF, it was the sexual violence that she viewed as the most debilitating, and it affected her both during and following the conflict:

Girls were dying of rape all around me. Every young girl was terrified of rape. The first time I was raped was by the commander who abducted me. . . . He left me bleeding. I was so afraid and I thought I was going to die like the other rape victims. . . . This commander continued having sex with me against my will. Other officers also came around and had sex with me. Even the young boys were attempting it. . . . Ever since I was raped, I get horrible stomach aches. I think it's because of the rapes.

In the aftermath of conflict, with no family or community ties outside of the RUF, Kadiatu's sense of insecurity remained and, in some ways, heightened. Highly conscious of the ongoing risk of sexual violence should she return to live with her RUF 'family', she felt she had no choice but to live on the streets of Freetown.

\section{Maria}

Maria was 15 years old at the time of the interview. Having been displaced and unable to locate her parents after the war, she was living in Freetown with a distant aunt and was attending school through the assistance of a local NGO. Maria had been abducted by the rebels at age 12 . Her sense of profound insecurity began following her abduction when she was initiated into the world of armed conflict through physical and technical training, as well as forced drug use:

I was captured in [region] and taken to a nearby village when I was 12 years old. . . Immediately following my abduction, I was trained to use a gun and fire. After the training with the guns, they would bring [a civilian] for us to kill. Each one of us was forced to kill. ... Soon after, I was injected with drugs in my back. ... I don't remember much after that, just going into action.

During her two years with the rebels, Maria reported ongoing sexual victimization by boy soldiers as well as by adult RUF commanders. However, it was her first experience of sexual violence that remained foremost in her mind:

I was raped the moment they captured me by an older man and I bled and bled. They gave me some medicine, but I could not walk. The man who raped me later carried me on his back. The same day other girls were raped too. They would just rape you and leave you. It happened to me so many times, I can't even count.

Maria expressed her profound distrust of men in the aftermath of conflict, and her feelings of profound shame at having been raped. Fearing stigma and rejection from her community, she reported having told no one, other than the research team, of her experiences of rape. 


\section{Hawa}

Hawa was 17 years old at the time of the interview. Not knowing the whereabouts of her parents or extended family since the war, Hawa had no permanent residence and travelled from place to place relying on the kindness of strangers to care for herself and her young child. Hawa had been abducted by the rebels at the age of nine and remained under their control for over five years. She described her abduction, the constant reality of sexual violence and the struggle to care for her child:

I was first abducted as a small girl and I was in total fear. I thought I would die at any time. During my time with the rebels, I was raped daily. At least one person would demand sex. For my very survival, I gave up myself and I was ready [for coerced sex] at all times. This was until a commander took me as his own and decided to have me as a permanent partner. He protected me against [sexual violence by] others.... Towards the end of the war, I became pregnant [with the commander's child]. . . . The child is now three years old. I have mixed feelings about the child. I feel happy because he is my everything now ... but I feel unhappy because I can barely support him [financially]. The baby's father abandoned me after the war.

The experiences of Kadiatu, Maria and Hawa illustrate the profound gendered insecurity endured throughout their captivity. While the entire experience of living among the RUF engendered insecurity on a multitude of levels and contexts, each girl placed an overwhelming emphasis on the insecurity brought forth by sexual violence. Importantly, the sexual violence cannot be understood simply as random outbreaks of social madness among the RUF, but rather as a method of ensuring compliance and asserting power, as well as a means of propagating terror. Foucault (1977) identifies atrocities (acts causing pain and suffering in the victim) as a mechanism used to display absolute power. Historically, he argues, the spectacle of the 'tortured body' was a dramatically staged event whereby public torture was used to demonstrate the state's absolute power and privilege. In a similar vein, sexual violence appears to have been used to assert power, as well as to deliberately humiliate, demoralize and weaken its victims. However, this humiliation and terror has much wider implications, as it may also work to strip the power and humanity from the larger group from which the victim is a part and instil a broader social degradation. Wartime sexual violence can thus be considered a symbolic war - one waged on the physical bodies of those least able to protect themselves and those least implicated in the war effort: girls and women.

For the individual victim, sexual violence has a profound effect on the mind and body through the scarring of memory and of flesh. In its aftermath, sexual violence brings forth a profound and long-term sense of insecurity, whether physical, psychological or socio-economic in nature. As evidenced in the experiences of Kadiatu, Maria and Hawa, this post-conflict insecurity manifested itself in ongoing shame, fear of continued sexual victimization, 
distrust, reproductive health problems and economic marginalization. Importantly, the girls' experiences illustrate that the end of hostilities does not guarantee an end to girls' sense of insecurity.

Responding to girls' continued sense of insecurity in the aftermath of conflict is an enormous challenge. Some have argued that the emerging human security agenda may provide a useful forum from which broader issues of gendered insecurity may be understood (Fox, 2004). The following section explores the human security approach and its capacity to respond to the plight of victims of wartime sexual violence.

\section{Responding to the Plight of Girls in Post-Conflict Societies: A Human Security Approach}

To its supporters, the notion of human security has been perceived as many things - a new paradigm, an emerging scientific field, a shift in the orientation and conceptualization of security, a political campaign, a set of beliefs about the sources of violent conflict, and a guide for academics or policymakers (Paris, 2001; Axworthy, 2004; Thakur, 2004). Still under development, the concept continues to be subject to ongoing debate and critique. It has, however, been viewed as a growing response 'to a situation wherein the continued prioritization of military concerns at the state level in traditional discourses and practices of security has served to further individual insecurity and failed to respond adequately to the most pressing threats to individuals throughout the world' (McDonald, 2002: 277).

Unlike traditional notions of security, which focus on the security of territory or governments, the human security model takes individuals and communities as its point of reference and argues that security policies must be more highly integrated with strategies for promoting human rights, democracy and development (Weissberg, 2003). The human security agenda also places an important emphasis on children and armed conflict, as well as the empowerment of women and girls. By introducing a distinctive conceptual breadth involving a much broader spectrum of actors and institutions, the model is said to be universally applicable and works to complement traditional notions of national security. The human security agenda is concerned with human life, human dignity, empowerment and security within not only the personal or community realm, but also in the realms of economics, food, health, environment and politics (UNDP, 1994). ${ }^{9}$

\footnotetext{
9 There has been much debate concerning the (f)utility of such a broad conceptualization. Critics question whether any threat could fall outside of the category of 'threats to human security' (Weissberg, 2003; Paris, 2001).
} 
With its emphasis on individuals and communities, particularly women and children, and the notion that a threat can be construed as any menace to the quality of life of the individual, the human security agenda may have great potential to raise the status of war-affected girls and address the challenges and fears that they may face, particularly post-conflict. As Fox notes, the approach has the capacity to provide a forum in which the current and future plight of war-affected girls 'can be recognized as a security concern, where rights abuses [including sexual violence] against them would be considered an insecurity problem and a threat to established norms' (Fox, 2004: 476). Similarly, the United Nations Commission on Human Security maintains that, in post-conflict societies, the human security model can empower individuals and communities, promote change, recast social, political and economic bases of power, and, perhaps more importantly for girl victims of sexual violence, provide 'opportunities for including the excluded, healing fragmentation and erasing inequalities' (UN Commission on Human Security, 2003: 58).

On a conceptual level, the human security approach may thus be an appropriate model to address and raise the profile of gender insecurity and wartime sexual violence. However, can the approach be successfully applied and implemented on a practical level, particularly in the aftermath of conflict? The Commission on Human Security suggests two general human security strategies post-conflict: protection and empowerment. Protection requires a 'concerted effort to develop norms, processes and institutions that systematically address insecurities'. Empowerment works to enable people to 'develop their potential and become full participants in decision-making' (UN Commission on Human Security, 2003: 1). The Commission argues that, if developed in full partnership with national and local authorities, and alongside an integrated human security framework that addresses public safety, humanitarian relief, rehabilitation and reconstruction, reconciliation and coexistence, and governance and empowerment, the two strategies have the capacity to achieve greater post-conflict recovery.

Reflecting the human security agenda, a number of processes have been established in postwar Sierra Leone to promote both protection and empowerment. Given their significance to girls and wartime sexual violence in post-conflict societies, three institutions and processes will be explored here. These include Sierra Leone's disarmament, demobilization and reintegration (DDR) programme, the truth and reconciliation commission, and the country's tribunal to punish perpetrators of wartime atrocities. 
Ensuring Protection: Disarmament, Demobilization and Reintegration

Disarmament, ${ }^{10}$ demobilization ${ }^{11}$ and reintegration ${ }^{12}$ are said to be crucial to increasing security, public safety and protection in the aftermath of conflict, as well as promoting peace. The 1998 report by the UN Secretary-General on 'The Causes of Conflict and the Promotion of Durable Peace and Sustainable Development in Africa' lists 'the reintegration of ex-combatants and others into productive society' as a priority of post-conflict peacebuilding (United Nations, 1998). Similarly, the Brahimi Report referred to demobilization and reintegration as key to postwar stability and to reducing the likelihood of conflict recurring (United Nations, 2000). Given its focus on both protection and peacebuilding, DDR represents an important aspect of the human security agenda (UN Commission on Human Security, 2003). Moreover, in the case of girls formerly associated with fighting forces, DDR programmes have the capacity to provide support to victims of sexual violence and promote girls' long-term security and socio-economic reintegration.

In Sierra Leone, plans for DDR were made explicit within the peace process. As a result, the Sierra Leonean government and international partners (including the Economic Community of West African States Monitoring Group and the United Nations Mission to Sierra Leone), conducted a formal DDR programme in three phases between 1998 and 2003. To qualify for entry to the DDR programme, combatants were required to present a weapon at any of the official reception centres across the country in order to 'disarm' and receive financial and educational benefits. By January 2002, when hostilities were officially declared at an end, 48,000 combatants had been disarmed and a total of 42,300 weapons and 1.2 million rounds of ammunition had been collected (Bah, 2004). Sierra Leone's DDR programming has been regarded as highly successful in increasing the country's security and viewed as a model on which other DDR processes could be based (Women's Commission on Refugee Women and Children, 2002).

Within the Lomé Agreement, explicit provisions were made to ensure the inclusion of child soldiers within the DDR process. However, informed by conventional views of gender roles, which tend to view armed conflict as a phenomenon occurring between males (who are seen as the key actors within a force), girls were rendered invisible under Sierra Leone's DDR programme. According to demobilization figures, between 1998 and December 2003 approximately 6,787 children were formally demobilized - 6,281 boys and a mere 506 girls (Mazurana \& Carlson, 2004). The very small proportion

${ }^{10}$ Disarmament is defined as the 'collection, control and disposal of all weapons including small arms, explosives, light and heavy weapons of both fighters and civilians' (United Nations, 2000: 15).

11 Demobilization is 'the process by which armed forces . . . either downsize or completely disband, as part of a broader transformation from war to peace' (UNDPKO, 1999: 15).

${ }^{12}$ Reintegration programmes 'are assistance measures provided to former fighters that would increase the potential for their and their family's economic and social reintegration into civil society' (UNDPKO, 1999: 15). 
of demobilized girls stems in part from their inability to benefit from the initial 'cash for weapons' approach to DDR, which was highly exclusionary. In Phases I and II of the programme, the 'wives' of male combatants, as well as their dependants, were not eligible for entry. Many girls reported being ordered to hand in their weapons prior to demobilization, and were left behind as their male colleagues were transported to assembly centres. Other girls indicated that their guns were taken away by their commanders and given to male fighters or, in some cases, sold to civilians who then reaped the financial benefits of the DDR programme. Group demobilization later became possible, with a group presenting one weapon between them. As a result more girls participated, yet the number still remained small (McKay, 2004).

Given the gender-discriminatory framework that saw girls (and women) only as 'wives' and 'camp followers', and not combatants, girls were not viewed as appropriate recipients of DDR benefits, such as skills training or schooling (McKay \& Mazurana, 2004). Therefore, in the aftermath of conflict, most girls either drifted to camps for the internally displaced in search of alternative forms of support, went directly back to their communities (referred to as 'spontaneous reintegration') or were taken in by helpful friends or adults. The vast majority of these girls thus experienced DDR not as 'protective' or 'promoting socio-economic reintegration', but instead as a struggle to fend for themselves and their children. In this sense, DDR in Sierra Leone essentially had the effect of extending gender-based power differentiation and gendered insecurity into the post-conflict era.

\section{Ensuring Empowerment: Sierra Leone's Truth and Reconciliation Commission}

Truth and reconciliation commissions (TRCs) are of particular relevance to both the human security agenda and the reality of victims of sexual violence, as they are said to have the capacity to promote healing, forgiveness and reparation, and to restore the dignity of victims and communities (Minnow, 1998). Given their very mandate of ensuring the inclusion of victims within the process, TRCs can be seen to reflect the human security agenda's strategy of 'empowerment'.

Sierra Leone's Truth and Reconciliation Commission (SLTRC) was conceived in July 1999 at the signing of the Lomé Peace Agreement. The SLTRC was established by an Act of Parliament in February 2000 to create an impartial historical record of violations and abuses of human rights and international humanitarian law related to the conflict. Having both fact-finding and therapeutic dimensions, the SLTRC intended to serve as the most legitimate forum for victims to 'reclaim their human worth and a channel for the perpetrators of atrocities to expiate their guilt, and chasten their consciences. The process has been likened to a national catharsis, involving truth telling, respectful listening and above all compensation for victims in deserving 
cases' (Solomon Berewa, cited in Schabas, 2003). The goals of the SLTRC were thus very much in line with an overall human security agenda, addressing the unique circumstances of individuals, communities, victims of sexual violence and children:

[The SLTRC seeks to] address impunity, to respond to the needs of victims, to promote healing and reconciliation ... giving special attention to the subject of sexual abuses and to the experiences of children within the armed conflict. (Lomé Agreement, article XXVI; emphasis added)

While very few truth commissions have paid attention to the plight of children during conflict, fewer still have sought to involve children in the truthseeking process (Cohn, 2001). Uniquely, children were an essential part of the SLTRC process, and child-friendly procedures were developed that ensured that children were protected when sharing their personal experiences of conflict. This included special hearings for children, closed sessions, protecting the identity of child witnesses and the training of staff in providing psycho-social support to children. Children were permitted to express themselves in a variety of ways, including oral declarations, signs and actions, drawings and written statements. Importantly, Sierra Leonean boys and girls, including former combatants, were involved in the design of procedures (UNICEF, 2005).

The commission began its public hearings in April 2003 and held closed hearings at the district level for women and children. The SLTRC collected 8,000 statements and received an additional 1,500 statements from the Campaign for Good Governance. Recommendations from children were included in the SLTRC's final report in 2004. More than 100 children participated in its drafting, and the Commission published the first ever 'childfriendly' version of such a report. Within the child version of the report, children proposed a 'Plan of Action' highlighting concrete ways that the report could be shared with children, both nationally and internationally, and ways in which the report's recommendations could be implemented in everyday practice.$^{13}$ Clearly, valuable efforts were made to be inclusive and to empower those who have been traditionally marginalized in peacebuilding processes.

\section{Protection and Empowerment: The Special Court for Sierra Leone}

Unlike TRCs, which tend to focus on healing, forgiveness and reparation, tribunals seek to achieve 'justice' through the punishing of offenders (UN Commission on Human Security, 2003). Tribunals can be considered 'protective', as they can lay the foundation for building respect for the rule of law

${ }^{13}$ For information on the 'Plan of Action', see http:/ / www.trcsierraleone.org/children/chapterseven.htm. 
and can strengthen the judicial system post-conflict. Moreover, by removing convicted offenders from society, they can be seen to protect the public. However, they can also be viewed as empowering, as they present an important opportunity to bring a measure of accountability in post-conflict societies by ending impunity and by allowing victims and their families to know that 'justice' has been attained (UN Commission on Human Security, 2003).

The Special Court for Sierra Leone (SCSL) was created jointly by the government of Sierra Leone and the United Nations to try those persons who bear 'greatest responsibility' for serious violations of international humanitarian law and the laws of Sierra Leone during the conflict. At the time of writing, thirteen individuals have been indicted; ten individuals are in custody, two have died, and one remains at large.

The SCSL represents a new model of international justice, often referred to as a 'hybrid' tribunal, in that it is staffed by both internationals and Sierra Leoneans rather than by an entirely international staff. Moreover, the SCSL's statute includes both domestic and international crimes as opposed to only international crimes. Underlining the focus on empowerment, the SCSL represents the first time an international war crimes tribunal has taken place inside the country in which the conflict took place, making it easier for victims to follow its proceedings.

Sexual violence and gendered insecurity are increasingly being recognized in the context of international tribunals. The conflicts in former Yugoslavia and Rwanda brought international attention to the issue of wartime sexual violence, and, following reports of widespread sexual atrocities, securing indictments for mass rapes became a political goal. Reports of mass rape were instrumental in the UN Security Council decisions to authorize the establishment of the International Criminal Tribunal for the former Yugoslavia in 1993 and the International Criminal Tribunal for Rwanda in 1994. Both tribunals, which included rape in the specific list of crimes constituting crimes against humanity and brought gender-based charges against the instigators of war crimes, represent a historic precedent in prosecuting sexual violence during armed conflict.

Under the SCSL, in recognition of the rampant sexual and gender-based violence that occurred throughout the conflict in Sierra Leone, acts of forced marriage are to be prosecuted as an 'inhumane act' - a crime against humanity - for the first time in the history of international law (SCSL, 2004). In fact, crimes against women and girls are the core charges for almost all of the current indictments issued by the Prosecutor's office, and include rape, sexual slavery and mutilation. As Chief Prosecutor David Crane ${ }^{14}$ explained:

These additional charges of crimes against humanity reflect the fact that women and girls suffered greatly during the war, including through widespread forced marriage.

14 The current Chief Prosecutor for the Special Court is Desmond de Silva, QC. 
... The Office of the Prosecutor is committed to telling the world what happened in Sierra Leone during the war, and gender crimes have been at the core of our cases from the beginning. (SCSL, 2004)

The SCSL's desire to ensure the protection and empowerment of Sierra Leoneans is illustrated in the following statement by Prosecutor David Crane to a group of students:

This is your Court. I encourage you to watch the trials closely. This is a truly historic moment, not just for your country, but for all of West Africa. Together, we will send a signal, regionally and internationally, that impunity for gross violations of human rights will no longer stand in Sierra Leone. (SCSL, 2003)

Each of the three aforementioned processes can be seen to reflect the human security agenda: The process of DDR sought to protect the public while simultaneously increasing security and contributing to the peacebuilding process. The SLTRC aimed to empower individuals and communities by addressing impunity and responding to the needs of victims. In turn, the SCSL sought to protect the public by punishing those bearing greatest responsibility for war crimes. Arguably, the Court can also be seen to promote empowerment by bringing a measure of accountability to Sierra Leone and allowing victims and families to know that justice will be realized. There is little doubt of the powerful symbolic and pragmatic importance of the three aforementioned processes for overall post-conflict recovery. However, what are girls' perceptions and direct experiences of each of these processes? Moreover, what impact have they had on girls' overall sense of security, protection, and empowerment in postwar Sierra Leone? These questions are addressed in the following discussion.

\section{Protection and Empowerment? Girls' Experiences in Post-Conflict Sierra Leone}

Relying on the voices of Hawa, Maria and Kadiatu, this section explores their perspectives and experiences with DDR, the SLTRC and the SCSL. The section also addresses the many psycho-social and economic challenges the girls face in the aftermath of the conflict.

\section{Perspectives on DDR, the SLTRC and the SCSL}

The three girls interviewed had differing experiences with DDR. Maria intentionally avoided the DDR process out of fear of stigmatization and potential prosecution: 
No, I didn't go through DDR. I was too afraid. I was afraid that people would be able to identify me and single me out as one of the bad people of the war. I didn't want anyone to learn that I had been with the rebels.

In contrast, Hawa and Kadiatu were able to benefit from DDR, particularly education and skills training. However, according to the girls, not only did DDR programming neglect to specifically address the after-effects of the sexual violence they experienced, it in fact appeared to perpetuate the problem. Kadiatu's experiences show that DDR camps can be perilous and insecure places for girls, where overcrowding and the weak application of the rule of law often expose girls to ongoing sexual violence and insecurity:

The [DDR] camp became chaotic and disorganized . . . there was no order. . . . The [camp]officers who were on night duty couldn't control the boys [ex- combatants]. The boys were coming over to [the girls] and harassing us for sex. I never felt safe.

The reality of sexual violence impelled Kadiatu to leave the DDR programme, even if the alternative meant living on the streets of Freetown.

In regards to the SLTRC and the SCSL, the three girls expressed their apprehension with both processes. In the case of the SLTRC, none of the girls felt that the commission would be beneficial or empowering to them personally, nor were they willing to testify at the proceedings:

Would I go to the TRC? No! It doesn't mean anything to me and won't benefit me.... I certainly wouldn't provide a statement. I don't want people to know I was with the rebels. (Maria)

It should be noted that other researchers have found similar distrusting views of the SLTRC among Sierra Leoneans. Shaw (2005) notes that excombatants in five districts in which she conducted research were almost universally fearful of the SLTRC, suspecting that information they gave to the SLTRC would find its way to the SCSL. She notes that in several communities people collectively agreed not to give statements.

Profound apprehension was also observed in relation to the SCSL. In particular, the girls expressed great concern that they would be prosecuted by the SCSL as a result of their former affiliation with the RUF. ${ }^{15}$ Instead of the Court providing a sense of protection or empowerment, girls felt a sense of apprehension and fear:

I fear the Special Court. The DDR programmers took our pictures and put them in the computer and we were given a card. I'm fearful that the government will take all the names in the computer and say: 'let's get rid of them all'. I'm afraid that they will put us in prison. (Hawa)

15 The UN Secretary-General and Security Council agreed to allow the prosecution of those aged 15 and over. However, the Chief Prosecutor made several public statements indicating that he would not prosecute children. 


\section{Girls' Lived Realities: Post-Conflict Marginalization and Survival}

Despite efforts at societal reconciliation and justice, instead of feeling empowered, protected or increasingly secure, girls reported that the postwar context has, in fact, been beset by family and community rejection, along with economic marginalization.

The three girls reported experiencing some form of rejection and stigmatization by their communities as a result of their former affiliation with the RUF. These experiences were reported as particularly debilitating:

[My community] refers to me as part of the 'evil ones'.... You know, they don't love me anymore. They despise me now. (Maria)

Importantly, girls appeared to suffer rejection not only as a result of their former affiliation with the rebels, but also because they had been victims of sexual violence. Given the importance placed upon virginity at marriage, girls were often deemed 'unmarriageable' following disclosures of rape. Moreover, in a society where girls are valued primarily for their future roles as wives and mothers, and where marriage is the best option for obtaining economic security and protection, being 'unmarriageable' often left girls feeling profoundly at risk. As Maria expressed:

I'm afraid I won't get a husband to marry me because of my past with the rebels. . . My aunt told me that no man will marry me now [that I am no longer a virgin]. I feel a sense of despair. What will happen to me? How will I manage?

Girls' marginalization had other economic consequences. Following a decade of war, Sierra Leone is plagued with economic stagnation, high unemployment, lack of educational opportunities and a weak civil society. With so few structural supports, the girls were living in impoverished circumstances, with little educational, financial or familial assistance. While Maria was able to attend school, Hawa and Kadiatu were surviving on the fringes of society with minimal or no opportunities for education and for remunerative work beyond informal petty trading. In response, Kadiatu reported that she had turned to prostitution and drug use in order to cope and survive.

In the light of these harsh psycho-social and economic realities, there was a natural inclination among the girls to regard 'peace' as disappointing. In fact, girls tended to view the post-conflict period as just as dispiriting as the period of war, sometimes even more so:

With the rebels, we ate the best food, we had access to money, and property within our controlled territory. Civilians were working for us - we were highly respected. Now I have nothing. I live on the street. I have no family and no future. (Kadiatu)

The challenges faced by these girls in post-conflict Sierra Leone are numerous and appear to affect diverse aspects of their lives. While the physical, sexual and emotional victimization of the girls was undeniably clear during the conflict, in its aftermath these girls are arguably bearing a form of secondary 
victimization. This post-conflict 're-victimization' is most evident in their socio-economic marginalization and exclusion, as well as the ongoing threats to their health and personal security. That similar conditions have been experienced by other former girl combatants (McKay \& Mazurana, 2004) is suggestive that the end of civil war and the establishment of DDR programming, the SLTRC or the SCSL have not necessarily meant an end to gender-based violence and insecurity in Sierra Leone.

\section{Challenging Dualism: A Structure-Action Approach to Human (In)Security}

On a conceptual level, through its focus on individuals and communities, the human security agenda can provide a powerful shift in a positive direction and ultimately has the capacity to raise the profile of war-affected girls and victims of sexual violence. Viewed in this light, the well-intentioned bottomup approach must be acknowledged and its many benefits recognized. However, the implementation of the human security agenda in everyday practice remains an ongoing challenge. Despite considerable efforts to promote the protection and empowerment of individuals and communities in Sierra Leone through DDR programming, the SLTRC and the SCSL, it appears that for victims of wartime sexual violence like Kadiatu, Maria and Hawa, who continue to live on the margins of society, such mechanisms cannot guarantee complete protection, empowerment, truth, immediate reconciliation or 'justice'.

A key question remains: why are processes that have been largely based on the principles of human security not sufficiently reaching war-affected girls and ensuring their protection and empowerment, particularly post-conflict? One obvious reason relates to gender exclusion. As reflected in Sierra Leone's DDR process, the unique needs of girls (and women) were largely overlooked. From a human security perspective, while DDR may have focused on the important goals of increasing individual security, protection and human dignity, it would appear that 'individuals' were regarded as either male or gender neutral. Indeed, DDR programming and other human security initiatives were not implicitly designed to address the intricacies of gender and the complexities of girls' lived realities, including sexual violence. However, this would seem to be only part of the problem.

Paradoxically, a central challenge in successfully implementing a human security approach may in fact stem from the emphasis on the individual, as well as from the assertion that the individual is the fundamental vehicle through which security is attained. When the sole focus is the individual, broader structural constraints, critical to understanding the lives of girls like 
Hawa, Kadiatu and Maria, are overlooked. Indeed, the human security approach appears to overemphasize the freedom that individuals have to construct their own social arrangements, as though they stood outside collective forces. In reality, much human insecurity appears to result from structural factors and unequal distributions of power that extend far beyond the reach of individuals like Hawa, Kadiatu and Maria. These structural realities inevitably influence and shape processes like DDR, the SLTRC and the SCSL that, in turn, have a profound impact on women's and girls' potential for attaining long-term post-conflict protection, empowerment and, ultimately, security.

The limitations of a solely 'individualized' approach to security are reflective of the micro-macro dualism that has long plagued social theory. A macro analysis tends to see society (and thus security) as a distinctive structural or supra-individual entity (Reed, 1992), whereby structural influences can be isolated and analysed without reference to individuals and the shared meanings through which individuals frame events. At the other extreme are micro analyses, which move away from viewing society as an entity that is largely independent of people. This perspective rejects the idea of structure, because the latter tends to 'dehumanize' people by robbing them of their essential characteristics as human beings and regards them as mere 'effects' of the encompassing structure (Becker, 1970). Therefore, micro analyses, which reflect some tenets of the human security approach, concentrate on the more personal and immediate aspects of social interaction in daily life and the face-to-face encounters between people (Layder, 1994: 57).

Although macro and micro perspectives have great individual merit, they each draw away from the essential connection between society and individuals, between structure and action. Criticisms of this dualism have been put forward by many social theorists, particularly Anthony Giddens. In connection with his theory of structuration, Giddens's work has been very much concerned with breaking down the divisions and entrenched micro-macro oppositions. Instead, his work has concentrated on the convergences and overlaps between them (Giddens, 1984). Giddens suggests that rather than seeing 'action' (individual agency, interaction and the micro features of society) and 'structure' (structural constraints, collective forces and the macro features of society) as oppositional elements of a dualism and mutually exclusive domains, we should instead regard them as the complementary terms of a duality - a 'duality of structure'. 'By the duality of structure' writes Giddens (1976: 121), 'I mean that social structures are both constituted by human agency, and yet at the same time are the very medium of this constitution'. In his theory of structuration, Giddens thus integrates two strands of social thought - his theory incorporates the full force of the human ability to contribute to the social world, while recognizing the limitations imposed by structure and the social context. 
Reflecting Giddens's approach, perhaps the goal of achieving greater longterm security for victims of sexual violence and war-affected girls is rooted neither in a completely individualized approach nor in a solely structural one. Instead, a combination of individual and structural factors needs to be integrated into the human security agenda. Such an approach would acknowledge the importance of the individual, as well as the active role of individuals in producing and contributing to their own social circumstances and security. Yet it would also recognize that an individual's scope and capacity for choice is bounded by historical, structural and institutional constraints. While the human security approach has admirably encouraged the protection and empowerment of the individual, it has not sufficiently addressed structural constraints and structural inequalities, which ultimately shape girls' (in)security. In Sierra Leone, for example, statistics indicate that women and girls face ongoing structural discrimination in practice, particularly in the areas of education, economics and politics. Girls remain the least educated sector of Sierra Leone's population (UNICEF, 2005). Females have unequal access to land and technology, and are less likely to be literate than males (Government of Sierra Leone, 2000). In the formal employment sector, women constitute only $40 \%$ of clerical staff and $8 \%$ of administrative and managerial staff (Ministry of Social Welfare, Gender and Children's Affairs, 2000). Moreover, women and girls are mainly involved in informal petty training, soap-making and tie-dying, where cash returns are low. Within the political arena, women were not granted the right to vote or to stand for election for political office until 1961. In the Northern province, women continue to be excluded from contesting and voting for elections for traditional leadership positions. Of the 149 paramount chiefs in the country, only three are female, all based in the south (Human Rights Watch, 2003). These examples provide a glimpse into only a few of the structural realities that work to thwart the long-term human security of girls and women.

To achieve greater long-term security for war-affected populations, including girls who have experienced sexual violence, human security initiatives aimed at individual protection and empowerment must occur alongside the reformation of existing social, political, economic and educational structures and institutions, particularly as they relate to gender. Cynthia Enloe (2000) has suggested that to understand the world better, we must take seriously the experiences of ordinary women and men, following the trail from national and international elite decisions, and broader structural constraints, back to the lives of ordinary people. This analogy bodes well for the present analysis, which calls for a 'structure-action' approach to human security intervention, whereby individual and broader socio-political structures are considered equally crucial to assuring the long-term post-conflict security of war-affected girls like Kadiatu, Hawa and Maria. 
* Myriam Denov is an Associate Professor at McGill University. Her current research and teaching interests lie in the areas of war and political violence, war-affected children, postconflict reconstruction and peacebuilding, and gender and security. She has been the principal investigator on a project funded by the Canadian International Development Agency (CIDA) that has explored the issue of former child soldiers in Sierra Leone, examining the long-term effects of the involvement of both boys and girls in armed conflict as victims, perpetrators, or both, as well as the rehabilitation needs of child soldiers following demobilization. She has worked with vulnerable populations internationally, including former child combatants, victims of sexual violence and people living with HIV/AIDS. Deepest thanks and gratitude go to the three girls whose stories are highlighted in this article. These young women offered their time and insights, and were unwavering in their commitment to this project. The author would like to thank each of them for their openness and candour, and for sharing their stories and experiences. The author is also very grateful for the generous support of the Canadian International Development Agency (CIDA) and the Child Protection Research Fund, which supported this research.

\section{References}

Abdullah, Ibrahim, 1998. 'Bush Path to Destruction: The Origin and Character of the Revolutionary United Front/Sierra Leone', Journal of Modern African Studies 36(2): 203-235.

Ashford, Mary-Wynne \& Yolanda Huet-Vaughn, 1997. 'The Impact of War on Women', in Barry Levy \& Victor Sidel, eds, War and Public Health. New York: Oxford University Press (186-197).

Axworthy, Lloyd, 2004. 'What Is Human Security? A New Scientific Field and Policy Lens', Security Dialogue 35(3): 348-349.

Bah, Alhaji, 2004. Implementing the ECOWAS Small Arms Moratorium in Post-War Sierra Leone, Ploughshares Working Paper 04-1. Waterloo, ON: Project Ploughshares.

Becker, Howard, 1970. Sociological Work. Chicago, IL: Aldine.

Cohn, Ilene, 2001. 'The Protection of Children and the Quest for Truth and Justice in Sierra Leone', Journal of International Affairs 55(1): 1-34.

Denov, Myriam \& Christine Gervais, 2006. Negotiating (In)Security: Agency and Resistance Among Girls Formerly Associated with Sierra Leone, unpublished manuscript.

Denov, Myriam \& Richard Maclure, 2006. 'Engaging the Voices of Girls in the Aftermath of Sierra Leone's Conflict: Experiences and Perspectives in the Culture of Violence', Anthropologica 48(1).

Denov, Myriam \& Richard Maclure, in press-a. 'Turnings and Adaptations: Militarization, Life Histories and the Making and Unmaking of Two Child Soldiers in Sierra Leone', Journal of Youth Studies.

Denov, Myriam \& Richard Maclure, in press-b. 'Girls and Small Arms in Sierra Leone: Victimization, Participation and Resistance', in Farr, Vanessa and Schnabel, Albrecht, eds, Gender Perspectives on Small Arms and Light Weapons. Geneva: United Nations University Press.

Enloe, Cynthia, 2000. Maneuvers: The International Politics of Militarizing Women's Lives. Berkeley, CA: University of California Press.

Foucault, Michel, 1977. Discipline and Punishment. New York: Pantheon.

Fox, Mary-Jane, 2004. 'Girl Soldiers: Human Security and Gendered Insecurity', Security Dialogue 35(4): 465-479. 
Gardam, Judith \& Hilary Charlesworth, 2000. 'Protection of Women in Armed Conflict', Human Rights Quarterly 22: 148-166.

Giddens, Anthony, 1976. New Rules of Sociological Method. London: Hutchison.

Giddens, Anthony, 1984. The Constitution of Society. Cambridge: Polity.

Government of Sierra Leone, 2000. The Status of Women and Children in Sierra Leone: A Household Survey Report (MICS-2). Freetown: Government of Sierra Leone.

Green, Jennifer, 2004. 'Uncovering Collective Rape: A Comparative Study of Political Sexual Violence', International Journal of Sociology 34(1): 97-116.

Hoogensen, Gunhild \& Svein Vigeland Rottem, 2004. 'Gender Identity and the Subject of Security', Security Dialogue 35(2): 155-171.

Human Rights Watch, 2003. We'll Kill You If You Cry: Sexual Violence in the Sierra Leone Conflict; available at http://www.hrw.org/reports/2003/sierraleone/.

Layder, Derek, 1994. Understanding Social Theory. London: Sage.

McDonald, Matt, 2002. 'Human Security and the Construction of Security', Global Society 16(3): 277-295.

Mack, Andrew, 2005. Human Security Report 2005: War and Peace in the 21st Century. Oxford: Oxford University Press.

McKay, Susan, 2004. 'Reconstructing Fragile Lives: Girls' Social Reintegration in Northern Uganda and Sierra Leone', Gender and Development 12(3): 19-30.

McKay, Susan \& Dyan Mazurana, 2004. Where Are the Girls? Girls in Fighting Forces in Northern Uganda, Sierra Leone and Mozambique: Their Lives During and After War. Montreal: Rights and Democracy.

Maclure, Richard \& Myriam Denov, 2006. "“I Didn't Want To Die So I Joined Them": Structuration and the Process of Becoming Boy Soldiers in Sierra Leone', Terrorism and Political Violence 18(1): 119-135.

Mazurana, Dyan \& Khristopher Carlson, 2004. From Combat to Community: Women and Girls in Sierra Leone. Washington, DC: Policy Commission of Women Waging Peace.

Ministry of Social Welfare, Gender and Children's Affairs, 2000. National Policy on the Advancement of Women. Freetown: Government of Sierra Leone.

Minnow, Martha, 1998. Between Vengeance and Forgiveness: Facing History After Genocide and Mass Violence. Boston, MA: Beacon.

Niarchos, Catherine, 1995. 'Women, War, and Rape: Challenges Facing the International Tribunal for the Former Yugoslavia', Human Rights Quarterly 17: 649-690.

Paris, Roland, 2001. 'Human Security: Paradigm Shift or Hot Air?', International Security 26(2): 87-102.

Peters, Krijn, 2004. Re-examining Voluntarism: Youth Combatants in Sierra Leone, Monograph no. 100. Pretoria: Institute for Security Studies.

Physicians for Human Rights, 2002. War-Related Sexual Violence in Sierra Leone: A Population-Based Assessment. Boston, MA: Physicians for Human Rights.

Reed, Michael, 1992. The Sociology of Organisations. London: Harvester Wheatsheaf.

Richards, Paul, 1998. Fighting for the Rainforest: War, Youth and Resources in Sierra Leone. Oxford: James Currey.

Schabas, William, 2003. 'The Relationship Between Truth Commissions and International Courts: The Case of Sierra Leone', Human Rights Quarterly 25: 1035-1066.

Seifert, Ruth, 1996. 'The Second Front: The Logic of Sexual Violence in Wars', Women's Studies International Forum 19(1/2): 35-43.

Shaw, Rosalind, 2005. Rethinking Truth and Reconciliation Commissions: Lessons from Sierra Leone, Special Report 30. Washington, DC: United States Institute of Peace.

Skjelsbaek, Inger, 2001. 'Sexual Violence and War: Mapping Out a Complex Relationship', European Journal of International Relations 7(2): 211-237.

South Asian Partnership Canada (SAP Canada), 2002. Women and Leadership: Voices for 
Security and Development, Forum Report. Ottawa: SAP Canada; available at http:// action.web.ca/home/sap/attach/Gender\%20ReportFinal.pdf.

Special Court for Sierra Leone: Office of the Prosecutor (SCSL), 2003. 'This Is Your Court: Prosecutor Addresses FBC Students', press release, 5 May.

Special Court for Sierra Leone: Office of the Prosecutor (SCSL), 2004. 'Prosecutor Welcomes Arraignment of RUF and AFRC Indictees on Charges Related to Forced Marriage', press release, 17 May.

Thakur, Ramesh, 2004. 'What Is Human Security? A Political Worldview', Security Dialogue 35(3): 347-348.

Twagiramariya, Clotilde \& Meredith Turshen, 1998. "Favours" to Give and "Consenting" Victims: The Sexual Politics of Survival in Rwanda', in Meredith Turshen \& Clotilde Twagiramariya, eds, What Women Do in Wartime: Gender and Conflict in Africa. London: Zed (101-117).

United Nations, 1998. The Causes of Conflict and the Promotion of Durable Peace and Sustainable Development in Africa, Report of the Secretary-General to the Security Council, S/2000/101. New York: United Nations.

United Nations, 2000. Report of the Panel on United Nations Peace Operations, A/55/3055$\mathrm{S} / 2000 / 809$. New York: United Nations.

United Nations Children's Fund (UNICEF), 2005. The State of the World's Children, 2005. New York: UNICEF.

United Nations Commission on Human Security, 2003. Human Security Now: Protecting and Empowering People. New York: United Nations Commission on Human Security.

United Nations Department of Peacekeeping Operations (UNDPKO), 1999. Disarmament, Demobilization and Reintegration of Ex-Fighters in a Peacekeeping Environment: Principles and Guidelines. New York: UNDPKO.

United Nations Development Programme (UNDP), 1994. Human Development Report. New York: UNDP.

Weissberg, Matthew, 2003. 'Conceptualizing Human Security', Swords \& Ploughshares: A Journal of International Affairs 13(1): 3-11.

Women's Commission on Refugee Women and Children, 2002. Precious Resources: Adolescents in the Reconstruction of Sierra Leone. New York: Women's Commission on Refugee Women and Children.

Zarkov, Dubravka, 2001. 'The Body of the Other Man: Sexual Violence and the Construction of Masculinity, Sexuality and Ethnicity in Croatian Media', in Caroline Moser \& Fiona Clark, eds, Victims, Perpetrators or Actors? Gender, Armed Conflict and Political Violence. New York: Zed (69-82). 